\title{
Wild Fruits Traditionally Gathered by the Malinke Ethnic Group in the Edge of Niokolo Koba Park (Senegal)
}

\author{
Mathieu Gueye ${ }^{1 *}$, Nicolas Cyrille Ayessou ${ }^{2}$, Souleye Koma1 ${ }^{1}$, Seydina Diop${ }^{1}$, \\ Leonard Elie Akpo ${ }^{3}$, Papa Ibra Samb ${ }^{3}$ \\ ${ }^{1}$ Laboratory of Botany, Department of Botany and Geology UMI 3189, IFAN Ch. A. Diop, Dakar, Senegal \\ ${ }^{2}$ Laboratoire de Formation Continue en Industries Agroalimentaires, Ecole Supérieure Polytechnique, \\ Université Cheikh Anta Diop, Dakar, Senegal \\ ${ }^{3}$ Department of Plant Biology, Faculty of Science and Technology, UCAD, Dakar, Senegal \\ Email: "gueye guirane@yahoo.fr
}

Received 13 February 2014; revised 22 March 2014; accepted 1 April 2014

Copyright (C) 2014 by author and Scientific Research Publishing Inc.

This work is licensed under the Creative Commons Attribution International License (CC BY).

http://creativecommons.org/licenses/by/4.0/

(c) (i) Open Access

\begin{abstract}
In rural areas, the local population draws from several forest resources needed for survival including food. Then it is a granary for these native people. Unfortunately, useful wild plants are highly threatened, especially by various human activities. Because of this situation we started with open semi-structured interviews to identify wild fruit plants, their consumed organs and their seasonality in the rural community of Tomboronkoto. Tomboronkoto is located at the edge of the Niokolo-Koba National park (Senegal) and is mainly inhabited by Malinke. We identified 45 wild fruit species belonging to $\mathbf{3 8}$ genera that can be divided in $\mathbf{2 8}$ botanical families. The more diversified are successively the Anacardiaceae, Tiliaceae, Apocynaceae and Caesalpiniaceae. More than half of the plants inventoried are trees (53\%). We can distinguish three categories of fruits depending on their Fidelity Level (FL) that informs us about their popularity: the well-known or common fruits, moderately known fruits and little known fruits. A dozen wild fruits happen to be greatly appreciated with very high fidelity level (100\% to $84 \%)$. The fruits of Saba senegalensis, Adansonia digitata, Parkia biglobosa, Tamarindus indica and Vitellaria paradoxa are the most variously used because they are appreciated being fresh or cooked. Only fruits of Ficussur are available all year long. The large majority of the most consumed fruits are available between the end of the hot dry season until the middle of the rainy season. This period coincides with the period where crops from the previous rainy season are depleted and the new crops are not yet ripe. Thus, these wild fruits would greatly contribute to food security in this area during the lean period.
\end{abstract}

"Corresponding author.

How to cite this paper: Gueye, M. et al. (2014) Wild Fruits Traditionally Gathered by the Malinke Ethnic Group in the Edge of Niokolo Koba Park (Senegal). American Journal of Plant Sciences, 5, 1306-1317.

http://dx.doi.org/10.4236/ajps.2014.59144 


\section{Keywords}

\section{Ethnobotany; Traditional Knowledge; Wild Edible Fruits; Malinke; Senegal}

\section{Introduction}

The importance of wild plants in the rural population's diet is widely recognized in the tropics and subtropics areas [1]-[5]. The strong anthropic pressure associated with ecosystem degradation due to deep soil and climatic changes is the main factor of loss of native genetic diversity. In addition, the degradation of natural resources and poverty in rural and urban areas are the main limiting factors for food security. In the region of Kédougou, 60\% of households live with food insecurity [6] and rural areas are particularly affected and vulnerable.

As the current international context is favorable to the protection of genetic resources and traditional knowledge, it, therefore, becomes imperative to start collecting traditional knowledge related to the phytobiodiversity.

Moreover, at the current rate of degradation, it seems necessary to collect this information and preserve this heritage in high biodiversity areas. The flora of Senegal is estimated at 3589 plant species dominated by vascular plants, which make up 2499 of them [7]. In Niokolo Koba Park, between Tambacounda and Kédougou regions 1500 are found [8] [9]. It's also showed that the south and southeast regions of Senegal had the greatest phytobiodiversity [7]. Malinke, for whom the forest's resources are essential to their survival, mainly populates the rural community of Tomboronkoto on the edge of Niokolo Koba Park. This is an area of high phytobiodiversity where several species are now in danger of extinction due to the proliferation of gold mining and industrial crops often made of exotic species. Useful wild species are seriously threatened, particularly the least known, generally slaughtered along with the knowledge surrounding them yet, as elsewhere, the local population draws from several forest resources needed for survival: food, medicine, building materials, etc. Faced with such a situation, it is imperative to develop programs of safeguard and valorization of the plants genetic resources. In addition, other studies [10]-[12] showed that some forest fruits are a constant supply of nutritional intake in rural areas.

For this reason, we undertook, on the one hand, the identification of wild plants whose fruits are traditionally consumed in the rural community of Tomboronkoto and secondly, the inventory of forms of consumption and periods of harvest.

\section{Materials and Methods}

\subsection{Study Area}

It belongs to the Sudano-Guinean domain and its proximity to the park offer the population a considerable diversity of plants. Tomboronkoto rural community located on the edge of Niokolo Koba, about $660 \mathrm{~km}$ from Dakar, in the region of Kédougou, department Kédougou Bandafassi district in Senegal has an area of $2267.9 \mathrm{~km}^{2}$ (Graph 1). Rural communities of Khossanto and Dialakoto border it to the north, south by the Bandafassi, to the east by the municipality of Kédougou and west by the National Niokolo Koba. The population is dominated by Malinke, has an estimated 7877 peoples and is distributed in 28 villages. It belongs to the Sudano-Guinean area and its proximity to the park offers the public a fairly wide variety of plants.

\subsection{Data Collection}

The study was conducted between2008 and 2010 for two field trips per year and in different seasons. We used the technique of open semi-structured interviews, which are participatory tools used for collecting several types of information from indigenous peoples. The semi-structured interviews were conducted using open, indirect and direct questions to learn about the different wild fruit species. The developed interview guide contains several aspects including:

- map resource that allows the inventory of species and their varieties, changes in their distribution in the area and traditional knowledge.

As we do not speak the local language, we have always sought the help of an interpreter-guide who is good with the language used in the area and who is familiar with the species. This guide was chosen after discussions with some villagers to ensure their knowledge of botany as well as their good reputation with regards to the landscape. 


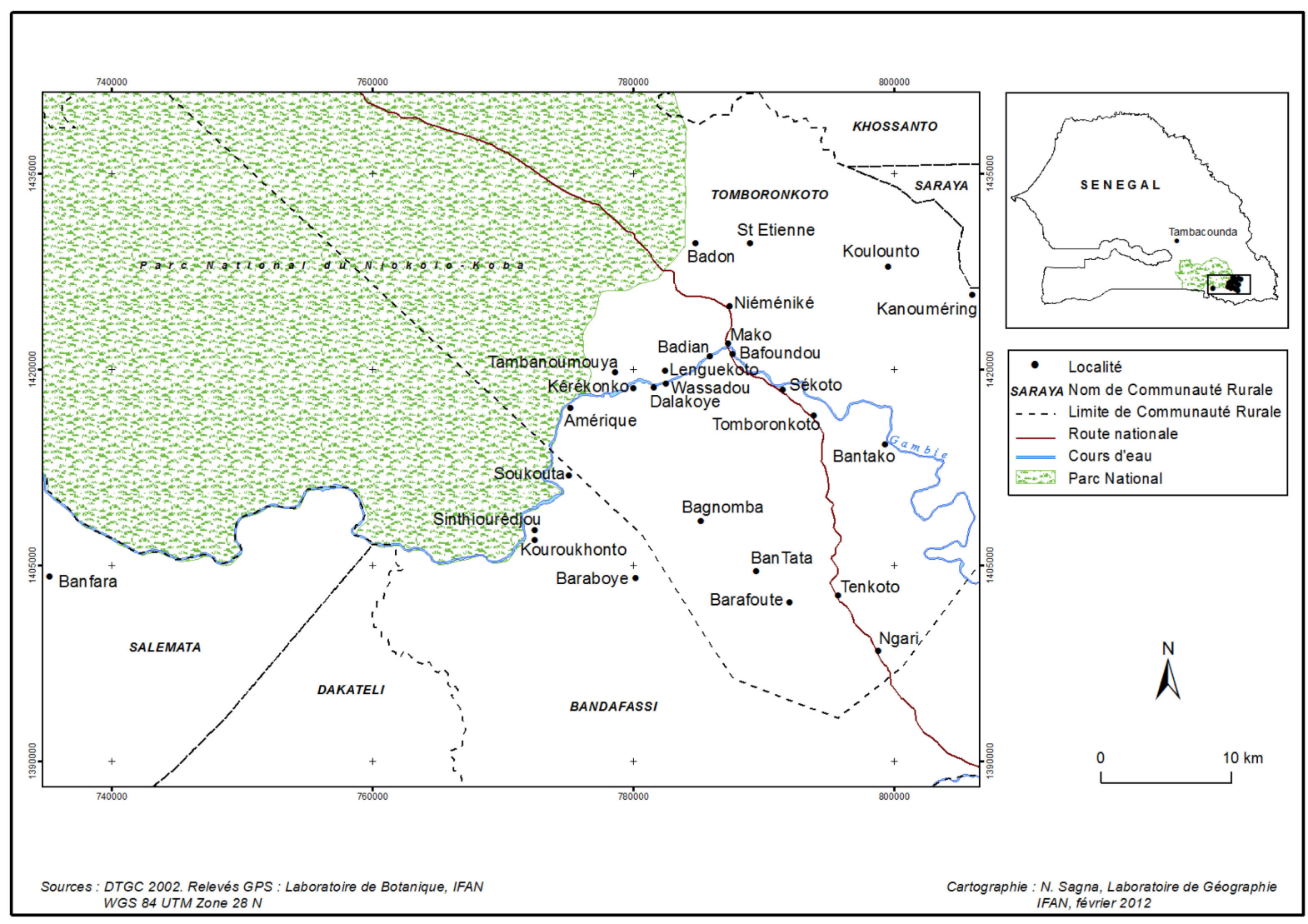

Graph 1. Location map of the villages visited in the rural community of Tomboronkoto (Kédougou, Senegal).

We began the process with focus groups at different villages. Group interviews allow for circulating information from all socio-economic strata of the village and generate fruitful discussion among their participants. In each village, after the focus group, one or two field trips are made to see the cited species and to collect herbarium specimens. The field trips were most often performed along with key informants offered by the villagers who showed us the species mentioned in the focus group.

Individual interviews were also conducted with the elderly and young. The selection of respondents was done with the help of people, taking into account their knowledge of the local flora. In such circumstances, the only criteria culturally operating on the value of an informant is the relative weight of his or her knowledge against the other members of the community or the reputation that he or she has [13]. Once we have selected informants we meet them all over the place (in the village, in the fields, panning for gold etc.). Whenever possible, individual interviews are made during walks in the woods as Cunningham suggests [14]. Thus, species are directly indicated by the informant and harvested immediately. In cases where the informant is too old or too busy after the interview, we relied on the knowledge of the guide-interpreter to collect specimens, and a second pass is made with the informant for validation crops.

The casual conversations to estimate knowledge and to elicit responses [15] were also used. Direct observations were also used.

In rural areas there is a lean season or seasonal hunger during which the local population lacks food. During this period of scarcity, people often begin picking edible forest plants valued for their leaves, fruits, tubers etc. To better assess the contribution of wild fruit in food security we organized focus groups and interviewed other people on the seasonality of the most consumed forest fruits. This exercise was first to divide the year into three seasons that are hot and dry, rainy, and finally cool and dry. These different seasons are represented on a large sheet of paper (Graph 2). Pictures of different fruits are distributed one by one. Whenever pictures of a given fruit are distributed we asked them to place the image on the representation of the different seasons to show us the harvest period of the fruit (Graph 2). This was done for the most frequently consumed fruits. 


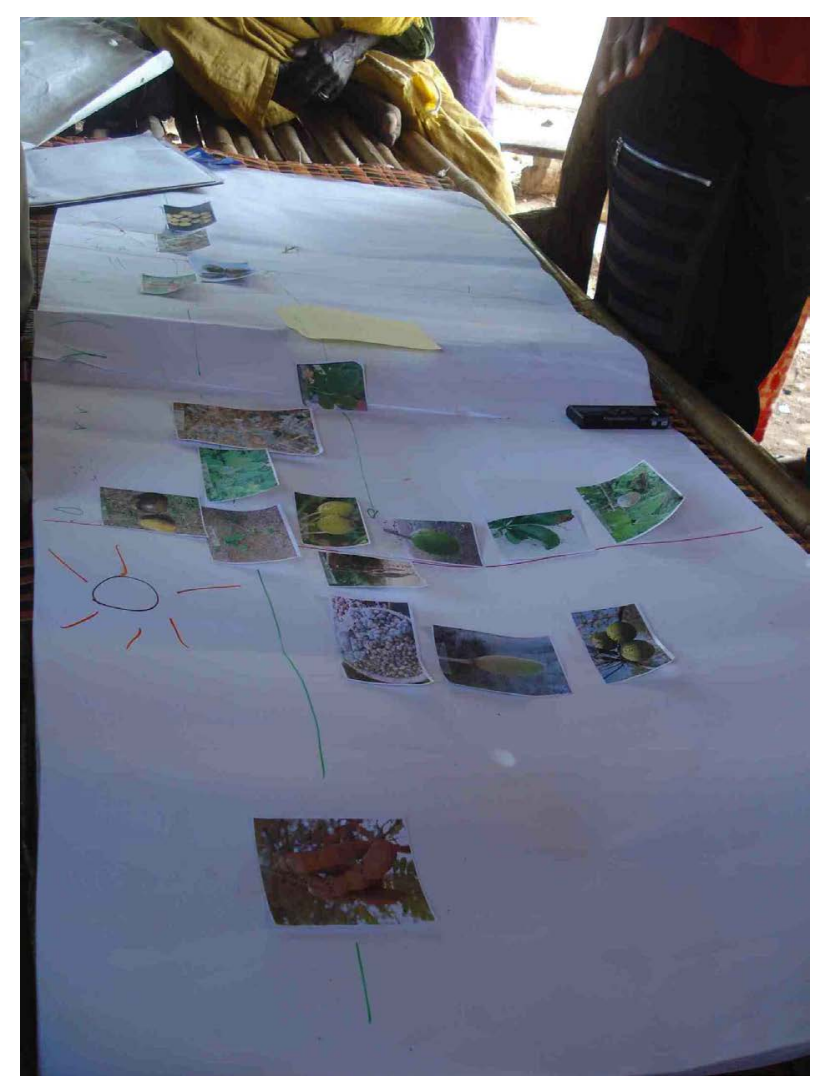

Graph 2. Overview of a seasonal calendar of the most consumed fruits in a focus group.

\subsection{Species Identification}

Some species are directly identified in the field, others in the laboratory using flora [16] and various structures [17] [18] or in comparison with units of IFAN's herbarium collection. For the selection of valid scientific names, we consulted the database of conservatory and botanical gardens of the city of Geneva

(http://www.villege.ch/musinfo/bd/cjb/africa/recherche.php), because this web site describe valid name of African plants.

\subsection{Data Analysis}

The data was processed using techniques of descriptive statistics.

Fidelity level (FL) is the percentage of informants citing the use of a given species in a category of well-defined purpose and is calculated using ethnobotanical analyzes [19] [20].

$$
\mathbf{F L}(\%)=(\mathbf{I p} / \mathbf{I u}) \times 100
$$

where Ip is the number of informants that used this part of a plant for a particular use; Iu is the number of informants that used plants as food for this use.

\section{Results}

\subsection{Fruit Tree Diversity}

At the rural community of Tomboronkoto, 45 wild fruit species were inventoried (Table 1). They are divided into 38 genera and 28 botanical families. The most significant are the Anacardiacea and Tiliaceae with five and four species, respectively. There are also Apocynaceae and Caesalpiniaceae with three species each (Table 1). Just over half of the species are trees (53\%), $40 \%$ are shrubs while creepers only constitute $7 \%$ (Table 1 ). 
Table 1. List of wild fruits species consumedby the Malinke ethnic group in the rural community of Tomboronkoto in the edge of Niokolo Koba Park (Senegal).

\begin{tabular}{|c|c|c|c|}
\hline $\mathbf{N}^{\circ}$ order & Species & Biological Type & Family \\
\hline 1 & Lannea acida A. Rich. & Tree & \multirow{5}{*}{ Anacardiaceae } \\
\hline 2 & Lannea microcarpa (Oliv.) Engl. & Tree & \\
\hline 3 & Lannea velutina A. Rich. & Tree & \\
\hline 4 & Sclerocarya birrea (A. Rich.) Hochst. & Tree & \\
\hline 5 & Spondias monbin L. & Tree & \\
\hline 6 & Annona senegalensis Pers. & Shrub & \multirow{2}{*}{ Annonaceae } \\
\hline 7 & Hexalobus monopetalus (A. Rich.) Engl. and Diels & Shrub & \\
\hline 8 & Carissa edulis (Forssk.) Vahl. & Shrub & \multirow{3}{*}{ Apocynaceae } \\
\hline 9 & Landolphia heudelotii A. DC. & Liane & \\
\hline 10 & Saba senegalensis (A. DC.) Pichon & Liane & \\
\hline 11 & Borassus aethiopum Mart. & Shaft & \multirow{2}{*}{ Arecaceae } \\
\hline 12 & Raphia palma-pinus (Gaertn.) Hutch. & Tree & \\
\hline 13 & Kigelia africana (Lam.) Benth. & Tree & Bignoniaceae \\
\hline 14 & Adansonia digitata $\mathrm{L}$. & Tree & Bombacaceae \\
\hline 15 & Cordia туха L. & Shrub & Boraginaceae \\
\hline 16 & Cordyla pinnata (Lepr. ex A. Rich.) Milne-Redhead & Tree & \multirow{3}{*}{ Caesalpiniaceae } \\
\hline 17 & Detarium microcarpum G. and Perr. & Tree & \\
\hline 18 & Tamarindus indica $\mathrm{L}$. & Tree & \\
\hline 19 & Neocarya macrophylla (Sabine) Prance GT former White & Tree & \multirow{2}{*}{ Chrysobalanaceae } \\
\hline 20 & Parinari excelsa Sabine & Tree & \\
\hline 21 & Diospyros heudelotii Hiern & Shrub & \multirow{2}{*}{ Ebenaceae } \\
\hline 22 & Diospyros mespiliformis Hochst. ex A. DC. & Tree & \\
\hline 23 & Pterocarpus santaloides DC. & Tree & Fabaceae \\
\hline 24 & Oncoba spinosa Forssk. & Shrub & Flacourdiaceae \\
\hline 25 & Icacina senegalensis Juss. & Shrub & Icacinaceae \\
\hline 26 & Strychnos spinosa Lam. & Shrub & Loganiacaea \\
\hline 27 & Trichilia emetica Vahl. & Shrub & Meliaceae \\
\hline 28 & Parkia biglobosa (Jacq.) R. Br ex G. Don & Tree & Mimosaceae \\
\hline 29 & Ficus sycomorus subsp. gnaphalocarpa (Miq.) CC Berg & Tree & \multirow{2}{*}{ Moraceae } \\
\hline 30 & Ficus sur Forssk. & Tree & \\
\hline 31 & Syzygium guineense (Willd.) DC & Shrub & Myrtaceae \\
\hline 32 & Ximenia americana L. & Shrub & Olacaceae \\
\hline 33 & Ziziphus mauritiana Lam. & Shrub & Rhamnaceae \\
\hline 34 & Gardenia erubescens Stapf and Hutch. & Shrub & \multirow{2}{*}{ Rubiaceae } \\
\hline 35 & Sarcocephalus latifolius (Smith) Bruce & Liane & \\
\hline 36 & Allophyllus africanus P. Beauv. & Tree & Sapindaceae \\
\hline 37 & Vitellaria paradoxa Gaertn. f. & Tree & Sapotaceae \\
\hline 38 & Quassia undulata (Guill. and Perr.) F. Dietr. & Tree & Simaroubaceae \\
\hline 39 & Cola cordifolia (Cav.) R. Br & Tree & Sterculiaceae \\
\hline 40 & Grewia bicolor Juss. & Shrub & \multirow{4}{*}{ Tiliaceae } \\
\hline 41 & Grewia lasiodiscus K.Schum. & Shrub & \\
\hline 42 & Grewia mollis Juss. & Shrub & \\
\hline 43 & Grewia tenax (Forsk.) Fiori & Shrub & \\
\hline 44 & Celtis toka (Forssk.) Hepper \& JRIWood & Tree & Ulmaceae \\
\hline 45 & Vitex madiensis Oliv. & Shrub & Verbenaceae \\
\hline
\end{tabular}




\subsection{Form of Fruit Consumption}

Fruits of identified species are widely used by the local population of Tomboronkoto. Within this group 93\% of the fruits are eaten directly (Graph 3). In addition only the fruits of three species (Allophyllus africanus, Kigelia africana and Raphia palma-pinus) are not directly consumed. The fruits of $29 \%$ of species are cooked before consumption while only the fruit of $13 \%$ of species are marketed (Graph 3).

\subsection{Classification of Wild Fruits}

Species are classified according to their fidelity level of reliability, which gives us information about their popularity in the community (Graph 4). This allows us to distinguish three categories of fruits: common or well-known fruits, moderately known fruits and little known fruits. Taking into account the level of their use, each category is divided into widely, moderately, or seldom used fruit (Graph 4). Common fruits represent 35.5\% of all consumed fruit and consist primarily of fleshy fruits (Plates 1(a)-(d)), the pulp is often eaten directly or cooked before consumption. The fruits of this category are widely used as 75\% of them are regularly harvested (Graph 4). Moderately known fruits (Plates 2(a)-(e)) comprise the smallest number with $13.3 \%$ of consumable fruits compared with 51\% of the least known fruits (Plates 3(a)-(d)). In these two categories of fruit, the level of exploitation is low to medium with $12 \%$ and $44 \%$ of heavily consumed fruit types used successively for the little known and moderately known fruit species (Graph 4).

\subsection{Consumption Patterns of Well-Known Fruits}

There are a dozen types of fruits, which are very popular in this locality (Graph 5). The group includes $67 \%$ of citations of all forest fruits. There are four species (Annona senegalensis, Hexalobus monopetalus, Lannea acida and Lannea velutina) whose fruits are used only to be eaten fresh (Graph 5). However, it should be noted that all the fruits of this group can be consumed directly and have a very high reliability index (100\% to $84 \%$ ). Only fruits of Borassus aethiopum and Tamarindus indica are eaten fresh less often, with indexes of $16 \%$ and $40 \%$ sequentially, unlike those of all other species that are very often (84\% - 100\%) eaten fresh in the bush or at home (Graph 5). The fruits of Saba senegalensis, Adansonia digitata, Parkia biglobosa, T. indica and Vitellaria paradoxa are the most diversely used as they are popular both fresh and cooked. They are also marketed and have reliability indices that vary depending on how they are used. S. senegalensis (100\%), Ziziphus mauritiana (87\%) and A. digitata (82\%) were the most traded fruit while fruit most commonly cooked before consumption are those of $T$. indica, Cordyla pinnata, V. paradoxa and P. biglobosa whose indices are between $72 \%$ and $86 \%$ (Graph 5).

\subsection{Seasonality of Well and Moderately Known Fruits}

Following the results of the focus groups conducted on the seasonality of the most consumed forest fruits it appears that there are two types of fruit: those eaten fresh, cooked and/or dried and can be prepared as a main dish and those often eaten as a delicacy or as a snack (Table 2). These are the most diverse, with 13 total species. Of all the types of fruits most commonly consumed only fruit from the Ficus sur are available year round (Table 2). All other fruits are only harvested during a one to three month period mainly at the end of the hot dry season and during the rainy season. Eight fruits are harvested during the rainy season, four during the hot dry season and one during the dry and cool season (Table 2). There are five fruits whose harvest periods begin during the hot dry season and end at the beginning of the rainy season. No fruit has availability that straddles the rainy season and the dry and cool season. The harvesting of fruit from the Tamarindus indica begins during the dry and cool season and ends early into the dry and warm season (Table 2).

\section{Discussion}

Diversity of wild fruit (45 species) inventoried in the Sudanese savanna Kédougou is quite high but still lower than that who reported that of the 75 Guinean savannas of Séguéla (north-western Côte d'Ivoire) [2], 55 have been investigated further. In the latter group 19 species are common to both areas of study. The difference between the two lists was mainly in belonging to two distinct climatic zones. However, it should be noted that we only questioned the villagers in their environment, unlike of Séguéla where the markets are visited [2]. Thus, species such as Dialium guineense and Detarium senegalense although their fruits are highly marketed throughout Senegal, are 


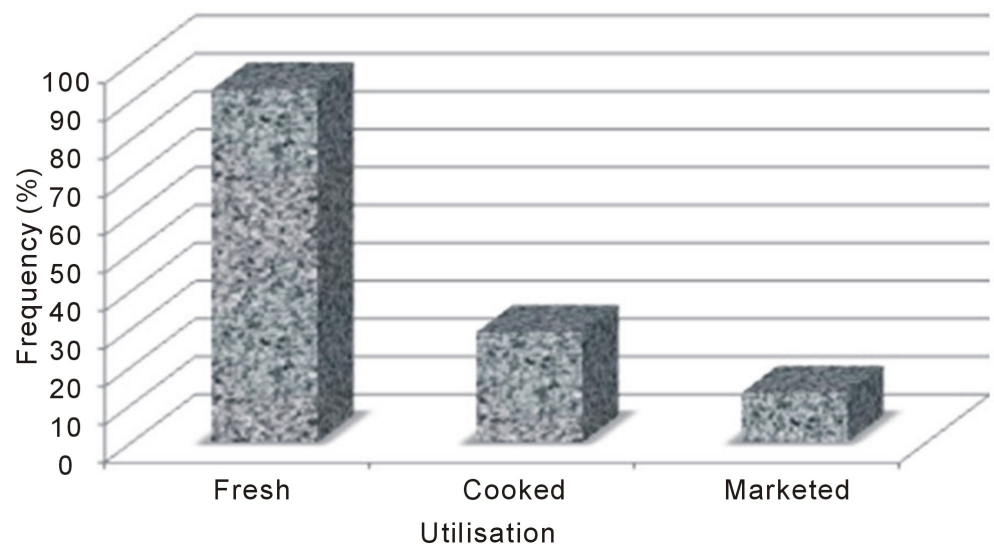

Graph 3. Importance of different forms using wild fruits inventoried in the rural community of Tomboronkoto in the edge of Niokolo Koba Park (Senegal).

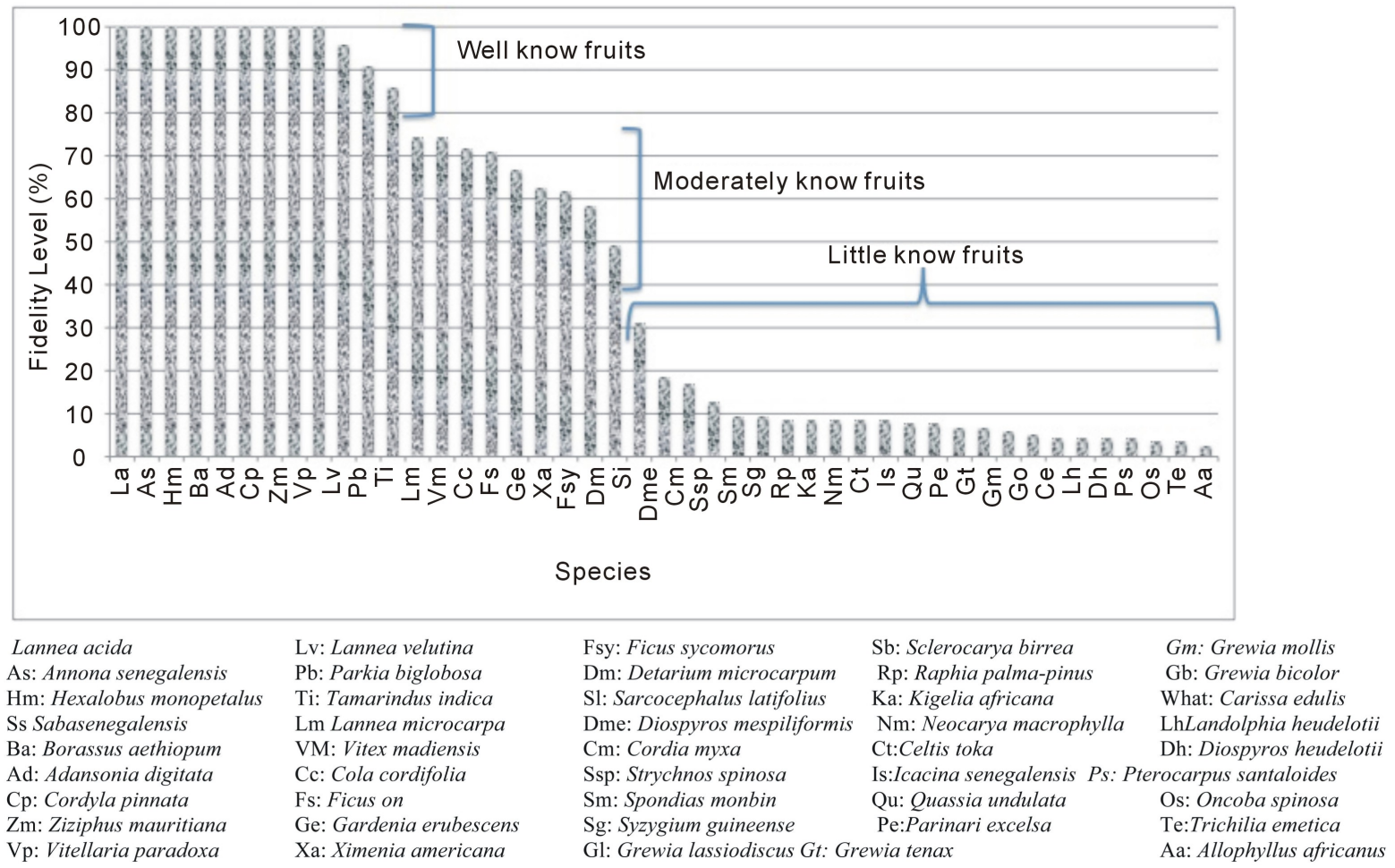

Graph 4. Classification of Wild fruits consumed by the Malinke ethnic group in the rural community of Tomboronkoto in the edge of Niokolo Koba Park (Senegal).

absent from this list. They were never mentioned during our interviews, and we did not encounter them during our field trips.

The level of knowledge and use of wild fruit is quite variable. Those with higher fidelity level are the best known and most widely consumed by the population of the rural community of Tomboronkoto. This group is constituted by well-known and moderately known fruit like in Ivory cost [2]. Eight of these fruits (Adansonia digitata, Annona senegalensis, Parkia biglobosa, Vitex spp. Sarcocephalus latifolius, Ficus sur, Vitellaria paradoxa, Lannea spp.) are also very popular in Séguéla [2].

Conversely, fruit with low fidelity level are the least known and least used. These are also dominant. This predominance of little known and underutilized species may be a result of the ignorance of certain species by 


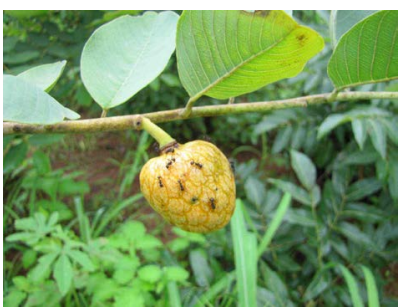

(a)

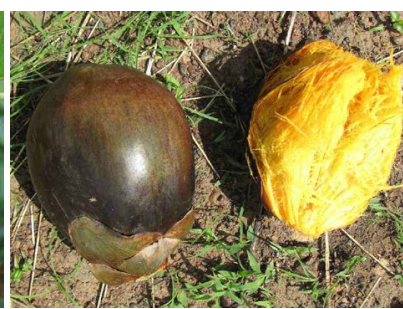

(b)

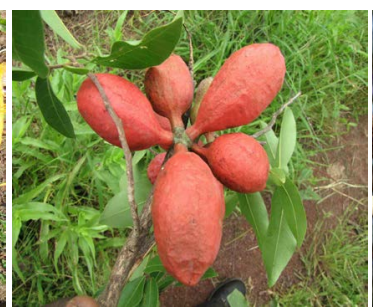

(c)

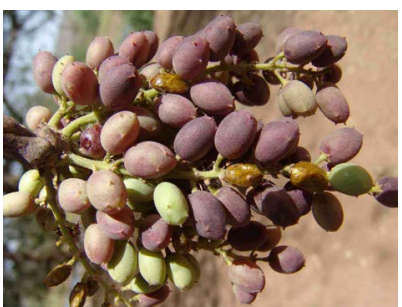

(d)

Plate 1. Well-known fruits. (a) Annona senegalensis Pers. (b) Borassus aethiopum Mart. (c) Hexalobus monopetalus A.Rich.; (d) Lannea acida A.Rich.

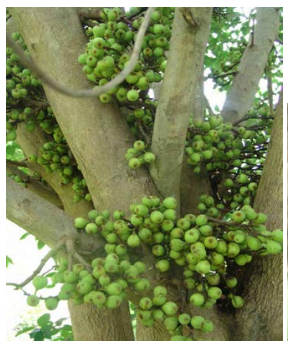

(a)

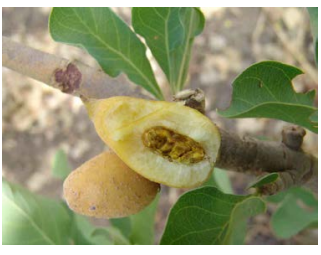

(b)

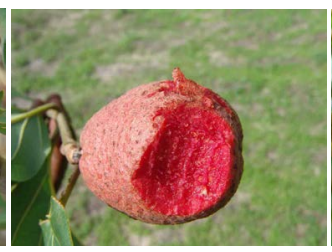

(c)

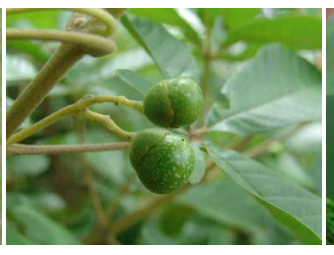

(d)

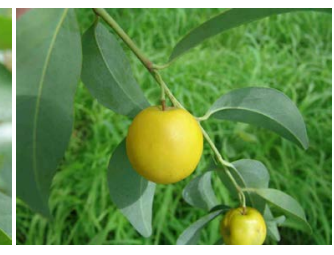

(e)

Plate 2. Moderately known fruits. (a) Ficus sur Forssk. (b) Gardenia erubecens Stapf and Hutch (c) Sarcocephalus latifolius (Smith) Bruce; (d) Vitex madiensis Oliv; (e) Ximenia americana L.

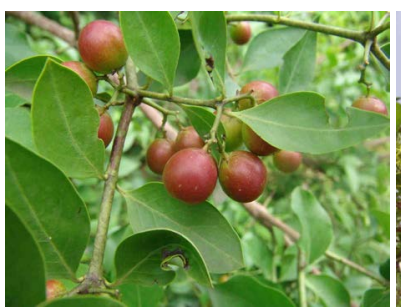

(a)

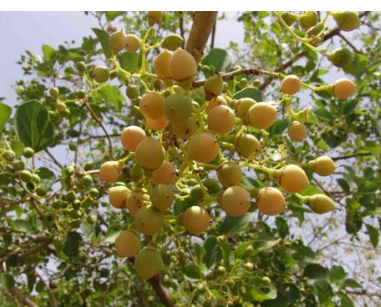

(b)

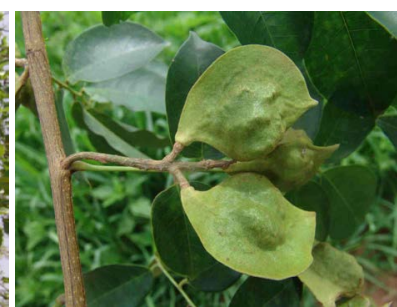

(c)

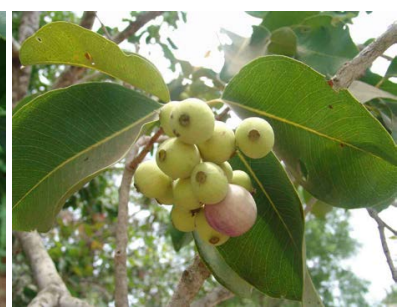

(d)

Plate 3. Little known fruits. (a) Carissa edulis (Forssk.) Vahl. (b) Cordia myxa L. (c) Pterocarpus santaloides DC. (d) Syzygium guineense (Willd.) DC.

younger people due in part by their rarity in the study area like Parinari excelsa, Landolphia heudelotii, Neocarya macrophylla and Syzygium guineense and secondly, by the change in eating habits noted in recent years [21]. This results together with a loss of knowledge on the part of the local population.

Many scarce foods are now replaced by imported food whose quality is not necessarily better. Such are the cases of the use of the fruits of Cordia myxa to sweeten porridge and fruit consumption Pterocarpus santaloides that once were the main dish of many families during the lean season [21]. The use of fruit C. myxa is supplanted by industrial sugar despite the risks.

Among the fruit species inventoried, it was reported that Vitellaria paradoxa, Parkia biglobosa and Lannea microcarpa are priority species during the lean period in Burkina Faso [22]. Some food species inventoried are also eaten in other regions, Ethiopia [23], Malaysia [24], Uganda [25] and Kenya [26].

The vast majority of the most commonly eaten fruits are available from the end of the hot dry season until the middle of the rainy season. This period coincides with that which is usually described as lean, when yields from the previous rainy season are depleted and the new crops are not yet ripe [27]. Thus, in view of our results, it seems that these wild fruits contribute significantly to the food security of the local population in the area during the lean period. In fact, at this difficult time they are one of the few food resources available to everyone. However, the reasons for consumption are mainly the lack of food, the alleged nutritional value of these foods and tradition. The last two reasons confirm what has been noted about traditional leafy vegetables in Senegal African type [1]. 


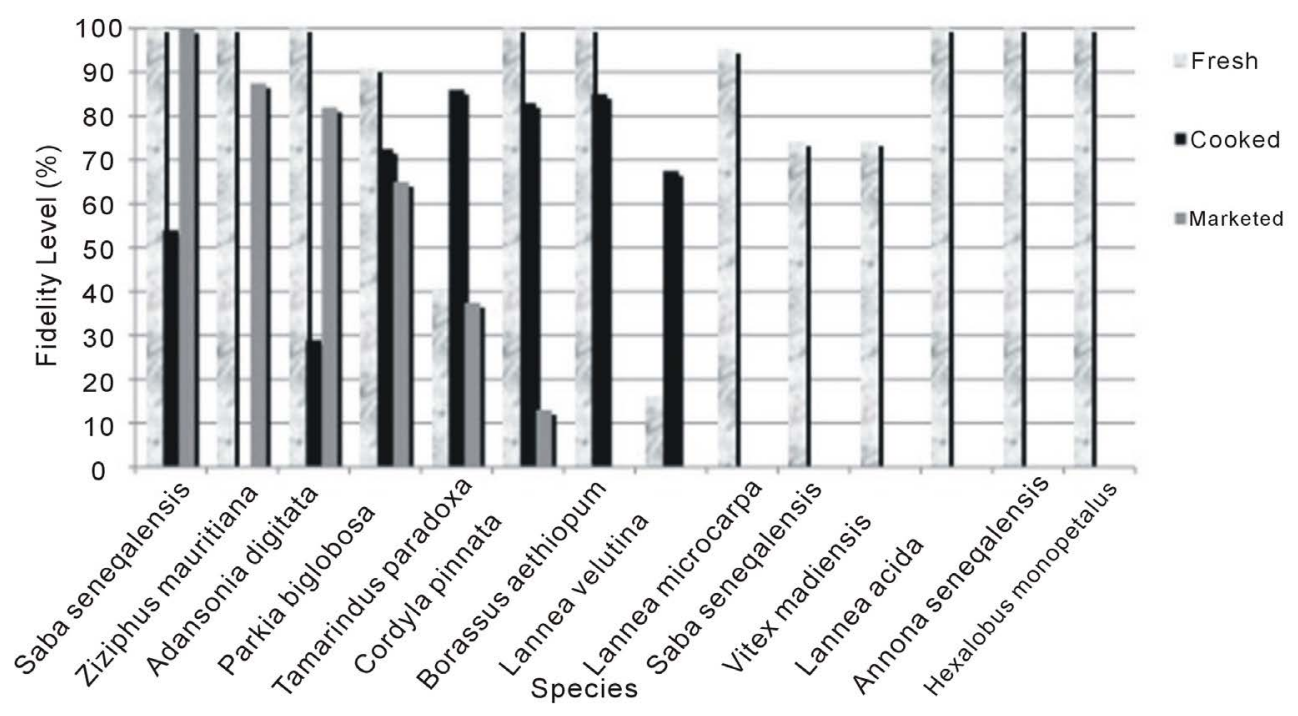

Graph 5. Frequency of different using forms of most consumed wild fruits by the Malinke ethnic group in the rural community of Tomboronkoto in the edge of Niokolo Koba Park (Senegal).

Table 2. Seasonal Calendar of the most consumed Wild fruits by the Malinke ethnic group in the rural community of Tomboronkoto in the edge of Niokolo Koba Park (Senegal).

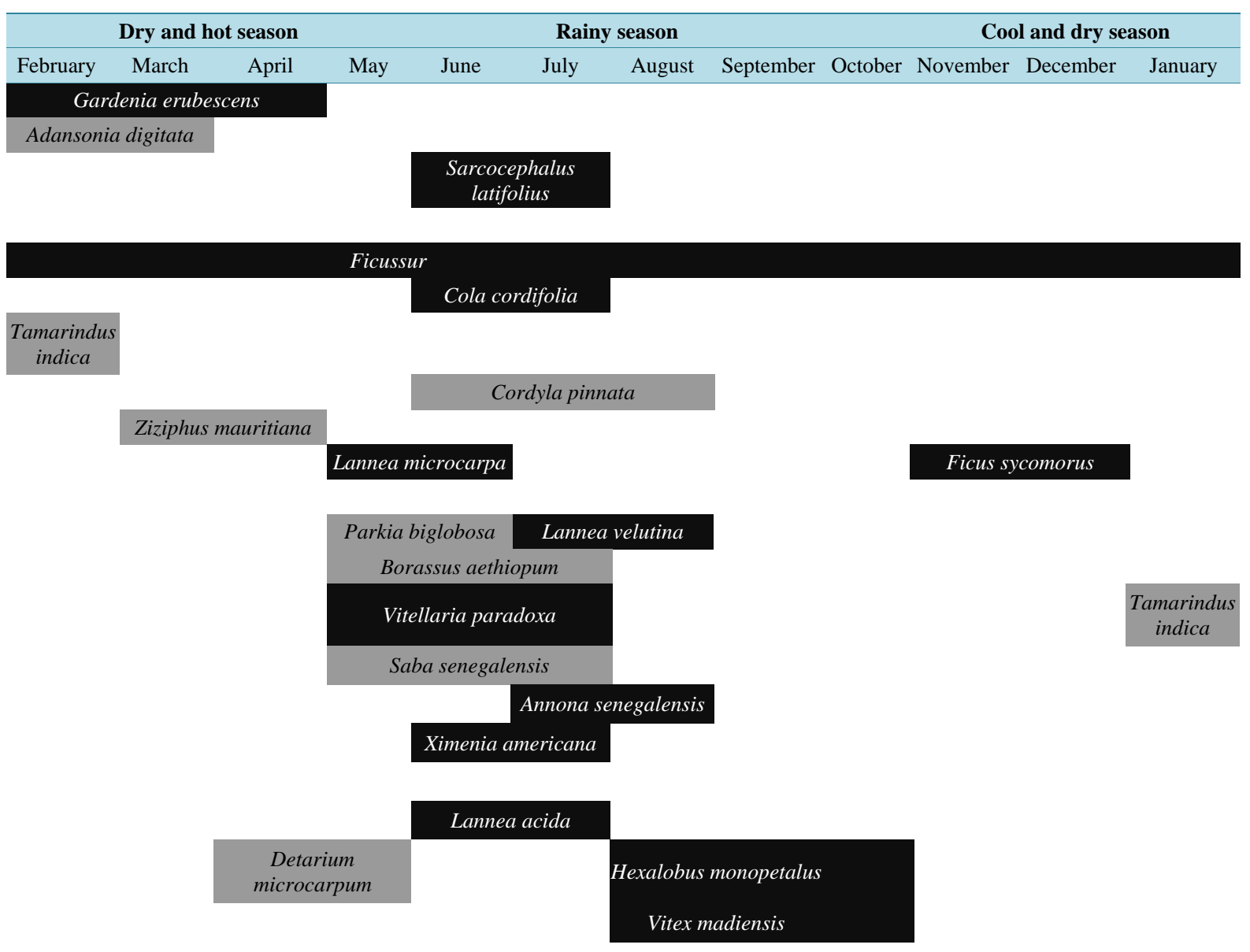


The contribution of wildlife in the livelihoods of the poor, especially in difficult areas, is more significant than we had previously believed [27]. Indeed, it was reported that rural forest areas show few signs of extensive malnutrition, though the quantity and quality of food available for consumption in West Africa is not sufficient enough to cover nutritional recommendations [28]. In fact, many forest products are consumed at the harvest site and are therefore not included in the overall balance of nutritionists [2] [21]. They are essentially fruits eaten as a snack or treat and are very rarely included in the preparation of main courses.

Rural populations have a good knowledge of forest foods and recognize their different qualities [21] [23] [29] [1] several of which have recently been scientifically confirmed by several authors [12] [30] [10] [11].

It was showed that the fruit of Maerua pseudopetalosa, a scarce food in the district of Kéniaba (Senegal), has a protein content similar to that of Vigna unguiculata and may therefore play a role in the diversification of diet and in the balance in areas with low agricultural productivity [11]. The fruit Sarcocephalus latifolius is also a good source of protein with a level approaching 20\% [10]. Proteins are the main food source of construction necessary for organisms doing heavy physical work and for those who are still growing (e.g. children), these fruits could be further introduced in infant feeding as foods for weaning and growth [11].

Analyses of other wild fruits (Icacina senegalensis, Cordyla pinnata, Ficus sycomorus subsp gnaphalocarapa and Sarcocephalu slatifolius) show that they are good sources of minerals [10]. However, acidity, vitamin C and total mineral content are different from one fruit to another. S. latifolius stands out from other fruits for its high acidity and higher content of vitamin $C$ while $I$. senegalensis and C. pinnata are richest in sugars. Such species can play a vital role in the fight against hunger and undernourishment [10].

It also appears that a better knowledge and valorization of these forest fruits can promote the conservation of biodiversity and contribute to the maintenance of resources and participate in the socio-economic development. Indeed, in some parts of Senegal conservation of trees in the forest parks is determined by the value of their product on the market [31].

This reveals how important the role of wild foods is in the balanced diet of rural people.

\section{Conclusions}

The participatory method used allowed for massive support from many people who were resources for this study, which gave us the opportunity to gather a wealth of information on the various wild fruit species. Plants are an important source of essential elements in rural life. To feed its population, Tomboronkoto harvests the fruits of forty-five species. The high diversity of species surveyed shows how important forest fruits are in the diet of Tomboronkoto. The level of knowledge and consumption of forest foods is highly variable. The collection focuses mostly on the best-known plants. For most of them, collection takes place during the lean season, and seems to indicate a strong contribution of these fruits to the food security of the population. However, since most food species are not well known, they still remain underutilized and poorly protected. Thus, the collection of various food crops in all climate zones must be made to guide the agro-food research to traditional foods while contributing to a better preservation of natural resources.

Even better, most often the rural population recognize these species for their several medicinal properties. So, in feeding, one is treated and/or protected from certain diseases, which only further increases the reason to use them. Therefore, biodiversity has to be taken into account to achieve the Millennium Development Goals (MDGs).

\section{Acknowledgements}

We are grateful toSouth-Plant Expert (SEP) program that funded this study. Also thank you to all the Malinke community for their warm hospitality and their availability. Cordially thanks to Mr Moussa Camara our guide interpréter.

\section{References}

[1] Guèye, M. and Diouf, M. (2007) Traditional Leafy Vegetables in Senegal: Diversity and Medicinal Uses. African Journal of Traditional, Complementary and Alternative Medecine (AJTCAM), 4, 469-475.

[2] Ambé, G.-A. (2001) Les fruitiers sauvages comestibles des savanes guinéennes de la Côte d’Ivoire: état de la connaissance par une population locale, les Malinké. Biotechnology, Agronomy, Society and Environment, 5, 43-58.

[3] Malaisse, F. (1997) Se nourrir en forêtclaireafricaine. Approche écologique et nutritionnelle. Gembloux, Belgique: Presses agronomiques de Gembloux, CTA, Wageningen, Pays-Bas, 384. 
[4] Vivien, J. and Faure, J.J. (1996) Fruitiers sauvages d’Afrique-Espèces du Cameroun. CTA, Wageningen, Pays-Bas, 416.

[5] Baumer, M. (1995) Arbres, arbustes et arbrisseaux nourriciers en Afriqueoccidentale. Enda Tiers-Monde, Dakar, 260.

[6] PAM (Programme Alimentaire Mondial) (2012) Evaluation de la sécuritéalimentairedans les zones à risque. Note de Synthèse, 14.

[7] Ba, A.T. and Noba, K. (2001) Flore et biodiversité végétale au Sénégal. Sécheresse, 12, 149-155.

[8] Adam, J.G. (1966) Composition floristique des principaux types de végétation du Sénégal. Journal of West African Science Association, 11, 81-97.

[9] Traore, S.A. (1997) Analyse de la flore ligneuse et de la végétation de la zone de Simenti (Parc national du Niokolo Koba), Sénégal oriental. Thèse de 3e cycle, Faculté des Sciences, Université Cheikh Anta Diop de Dakar, 136.

[10] Ayessou, C.N., Ndiaye, C., Cissé, M., Guèye, M. and Sakho M. (2011) Nutritional Contribution of Some Senegalese Forest Fruits Running across Soudano-Sahelian Zone. Food and Nutrition Sciences, 2, 606-612. http://dx.doi.org/10.4236/fns.2011.26085

[11] Ayessou, N.C., Guèye, M., Dioh, E., Konteye, M., Cissé, M. and Dornier, M. (2009) Composition nutritive etapporténergétique du fruit de Maeruapseudopetalosa (Gil et Gil-Ben) DeWolf (Capparidaceae), aliment de soudure au Sénégal. Fruits, 64,147-156. http://dx.doi.org/10.1051/fruits/2009010

[12] Danthu, P., Soloviev, P., Totté, A., Tine, E., Ayessou, N., Gaye, A. and Niang, T. (2001) Caractères physico-chimiques et organoleptiques comparés de jujubes sauvages et des fruits de la variété Golaintroduite au Sénégal. Fruits, 57, 173-182. http://dx.doi.org/10.1051/fruits:2002016

[13] Grenand, P., Moretti, C., Jacquemin, H. and Prévost, M.F. (2004) Pharmacopées traditionnelles en Guyane. Ed. IRD Paris, France.

[14] Cunningham, A.B. (2002) Applied Ethnobotany: People, Wild Plant Use and Conservation. People and Plants Conservation Manual. Earthscan, 300.

[15] Martin, G.J. (2004) Ethnobotany. A Method Manual. Earthscan Publications, London.

[16] Berhaut, J. (1967) Flore du Sénégal plus complète avec les forêts humides de la Casamance. Ed. ClairAfrique, 485.

[17] Hawthorne, W. and Jongkind, C. (2006) Woody Plants of Western African Forests: A Guide to the Forest Trees, Shrubs and Lianes from Senegal to Ghana. Ed. Royal Botanic Gardens, Kew, 1023.

[18] Arbonnier (2000) Arbres, Arbustes et Lianes des Zones Sèches d'Afrique de l'Ouest. Ed. CIRAD-MNHN-UICN, Paris.

[19] Begossi, A. (1996) Use of Ecological Methods in Ethnobotany: Diversity Indices. Ecological Methods in ethnobotany, 50, 280-289.

[20] Trotter, R.T. and Logan, M.H. (1986) Informant Consensus: A New Approach for Identifying Potentially Effective méDicinal Plants. Ed. Bedfore Hills, New York, 91-112.

[21] Guèye, M. (2012) Etude ethnobotanique chez les Malinké de la Communautérurale de Tomboronkoto (Région de Kédougou) etvalorisation des collections historiques de l'Herbier de l'Institutfondamentald'Afrique noire (IFAN) Ch. A. DIOP/UCAD.Thèse de Doctoratd'Étatès Sciences Naturelles, UCAD, 176.

[22] Thiombiano, D.N.E., Lamien, N., Dibong, D.S., Boussim, I.J. and Belem, B. (2012) Le rôle des espèces ligneuses dans la gestion de la soudure alimentaire au Burkina Faso. Sécheresse, 23, 86-93.

[23] Teklehaymanot, T. and Giday, M. (2010) Ethnobotanical Study of Wild Edible Plants of Kara and Kwego Semi- Pastoralist People in Lower Omo River Valley, Debub Omo Zone, SNNPR, Ethiopia. Journal of Ethnobiology and Ethnomedicine, 6, 23. http://dx.doi.org/10.1186/1746-4269-6-23

[24] Ong, H.-C., Chua, S. and Milow, P. (2011) Traditional Knowledge of Edible Plants among the Temuan Villagers in Kampung Jeram Kedah, Negeri Sembilan, Malaysia. Scientific Research and Essays, 6, 694-697.

[25] Katende, A.B., Ssegawa, P. and Bernie, A. (1999) Wild Food Plants and Mushrooms of Uganda. Technical Handbook No. 19, Ed. RELMA, 490.

[26] Maundu, P.M., Ngugi, G.W. and Kabuye, C.H.S. (1999) Traditional Food Plants of Kenya. Ed. Kenya Ressource Centre for indigenous Knowledge (KENRIK), National Muséum of Kenya, 270.

[27] Norman, D.W. and Dixon, J (1995) Sustainable Dryland Cropping in Relation to Soil Productivity. FAO Soils Bulletin 72. Food and Agriculture Organisation, United Nations. http://fao.org/docrep/V9926E/V9926E00.htm

[28] Gautier-Bréguin, D. (1992) Plantes de cueillette alimentaire dans le Sud du V-Baoulé en Côte d’Ivoire. Description, écologie, consommation et production. Boissiera, 46, 1-341.

[29] Diouf, M., Lô, C., Guèye, M. and Mbengue, N.B. (2007) Sélection participative de nouveaux cultivars de quatre (4) espèces de légumes feuilles (Hibiscus sabdariffa L., Amaranthus L. spp, Vigna unguiculata (L.) WALP et Moringa oleifera Lam) au Sénégal. African Journal of Food, Agriculture, Nutrition \& Development (AJFAND), 7. 
[30] Ayessou, C.N., Ndiaye, C., Cissé, Gueye, M. and Sakho, M. (2013) Nutritional potentiel of Dialium guineense Willd fruit. Journal of Food Composition and Analysis (JFCA) (in Press). http://dx.doi.org/10.1016/j.jfca.2014.01.002

[31] Ndour, B., Sali, P.N., Samba, A.N.S. and Sène, A. (1999) Bilanet evaluation des activités de SALWA $1990-1999$ au Sénégal, ICRAF, Kenya, 19. 